Article

\title{
Bicycle Sharing: Sustainable Value Creation and Institutionalisation Strategies in Barcelona
}

\author{
Julia Winslow and Oksana Mont *i \\ International Institute of Industrial Environmental Economics, Lund University, P.O. Box 196, 22100 Lund, \\ Sweden; julia.winslow.3516@student.lu.se \\ * Correspondence: oksana.mont@iiiee.lu.se
}

Received: 9 January 2019; Accepted: 28 January 2019; Published: 30 January 2019

\begin{abstract}
A highly debatable issue is whether or not a paradigm shift toward the sharing economy could help to address the economic, social and environmental challenges of our time. This article contributes to the academic discussion by exploring the types of value created by sharing organisations and the strategies they use to institutionalise themselves in relation to powerful institutions. The study applies two analytical frameworks, based on value creation and institutional strategies, to three empirical case studies of bicycle sharing systems (BSS) in Barcelona. Rich data was collected from a variety of primary and secondary sources, including a field visit to Barcelona, interviews with representatives of the three bicycle sharing systems, observations and literature analysis. We found that the environmental value these organisations create is closely interlinked with the social value they produce and that these values outweigh negative impacts of their operations. All case organisations employ regulative, normative and cultural-cognitive strategies for their institutionalisation but are also subject to powerful institutions beyond their individual control. We recommend that entrepreneurs, city officials, the public and other stakeholders engage in collaborative and open development processes to shape the emerging sharing economy alongside the institutional work of sharing organisations.
\end{abstract}

Keywords: bicycle sharing systems; business models; value creation; institutionalisation strategies; environmental; economic and social sustainability

\section{Introduction}

According to the international research organisation Global Footprint Network, humanity is consuming natural resources faster than they can be replenished-it would take 1.7 Earths to sustain current global rates of consumption [1]. If we continue with business as usual, this footprint will be amplified to the equivalent of three Earths by 2050 [2], when the global population is projected to reach 9.8 billion [3].

The global financial crisis, widening social inequalities and rapidly approaching ecological thresholds are revealing disparities in the regulatory, social and cultural systems that have driven unsustainable mass consumption for the past four decades. As a result, public trust in institutional bodies such as governments, banks, businesses, media and NGOs is in global decline [4]. At the same time, there is evidence that values and norms are shifting towards more mindful consumption [5]. In parallel, developments in technology are enabling better, decentralised connections between supply and demand by facilitating trust between strangers [6].

These developments may be seen as part of a shift towards a market system known as the 'sharing economy'. It is based on decentralised production, consumption, finance and learning-driven by connected individuals and communities across distributed networks [6]. The sharing economy has fostered innovative business models that are challenging traditional institutions of consumption and production, by selling access instead of ownership and enabling consumers to become producers themselves [7]. 
The sharing economy holds promises of economic empowerment for individuals, improved social cohesion and reduced environmental impact by decreasing demand for new products [8]. However, what some consider "a greener form of capitalism" [9] is regarded by others as "neoliberalism on steroids" [10]. Sharing organisations such as Airbnb and Uber-which began as small, grassroots market disruptors-have today grown into near-monopolies. They make huge profits from the value created by their users and strategically bypass laws and regulations, with little evident regard for the environment or social justice [10].

The reality is probably somewhere in between. Currently, there is a lack of conceptualisations and hands-on tools to evaluate the value these organisations deliver not only for the economy and shareholders but also for the environment and society [11,12]. Consequently, there is still a lack of understanding of whether business models in the sharing economy can actually deliver sustainable value [7]. Several studies have analysed economic value created or destroyed by business models in the sharing economy [13] but sustainability aspects are often overlooked [14] and cases are often analysed outside their organisational, institutional or geographical contexts. The first aim of this article is therefore to develop an analytical framework for Sustainable Value Creation, based on extant literature [15] and then test it by analysing three cases of bicycle sharing systems.

The sharing economy is an emerging field that has not yet established the necessary regulative, normative and cultural-cognitive institutions under which its true potential can unfold [16]. However, this is an influential stage in the development of a new market, if not a new economic paradigm [8]. It is an opportunity for the public, entrepreneurs, competitors and governments to actively engage in shaping the regulations, norms and behaviours that can influence the sharing economy in ways that enable it to deliver its alluring promise. For that, there is a need to understand the institutional forces that enable or inhibit the development of the sharing economy [17] and the role of sharing organisations in shaping their institutional context [18]. Indeed, there is growing interest among academics studying the sharing economy to understand the interactions between new actors and age-old institutions [19]. Mont, Voytenko Palgan and Zvolska [17] propose a model for analysing the institutionalisation strategies employed by sharing organisations but it needs to be tested empirically. The second aim of this article is therefore to test the proposed model as an analytical framework for understanding institutionalisation strategies of sharing organisations.

Based on these aims, specific research questions addressed in this study are:

1. What types of value do bicycle sharing systems create?

2. What strategies do bicycle sharing systems use to institutionalise themselves?

We apply the developed Analytical Framework for Sustainable Value Creation and test a second framework for analysing the institutionalisation strategies in three empirical case studies of bicycle sharing systems in Barcelona.

Barcelona was chosen for several reasons. The capital of the autonomous region of Catalonia in Spain is a metropolis, struggling with a large population, a high vehicle density and air pollution. It lacks a traditional cycling culture but experienced a cycling boom after the introduction its public bicycle sharing scheme, Bicing, in 2007. The scheme was one of the first and largest of its kind in Europe. The sharing economy is the subject of heated debate in Barcelona [20-22]. On the one hand, it provides economic opportunities that are helping citizens to help themselves during Spain's nine-year economic downturn. On the other, it has exacerbated the city's housing crisis by raising prices of rental properties, especially through Airbnb. A previous evictions activist, Ada Colau, is now the city's first female mayor. She is critical of Airbnb and Uber-figureheads of the sharing economy-for their lack of enforcement on permits. At the same time, as mayor, Colau is promoting the social and solidarity economy (SSE), based on non-profit peer-to-peer (P2P) solutions to address the municipality's economic and social challenges [23].

The article is structured as follows: The next section briefly outlines extant knowledge on value provision and institutionalisation in the sharing economy. The analytical framework for Sustainable 
Value Creation is then developed and the framework for Institutionalisation Strategies presented. Section 3 describes methods of data collection and analysis. Section 4 analyses the empirical data using the frameworks, while Section 5 offers a discussion of the results, provides conclusions and outlines future research directions.

\section{Theoretical Background}

The sharing economy has been defined as "an economy built on distributed networks of connected individuals and communities versus centralized institutions, transforming how we can produce, consume, finance and learn" [6]. It gives users easy and temporary access to products that are already available on the market, relieving them from the high transaction costs involved in buying a new product [7]. It also enables providers to make a profit from products they already own that have high idling capacity [7]. From an environmental perspective, it is hypothesised that the sharing economy can save resources by maximising utilisation rates of existing products, thereby reducing demand for new goods [24]. The social interactions created by peer-to-peer platforms are also believed contribute to community building and social cohesion [8].

However, sceptics warn that the money earned in the sharing economy may be used to purchase new products or that the creation of new market opportunities may increase the purchasing power of a society, thereby increasing overall environmental impact [24]. From a social perspective, the sharing economy can actually increase social impacts through unevenly distributed profits and commercialisation of the moral practice of sharing [24]. The monopolies of Airbnb and Uber have shown that issues such as exploitation of labour, limited liability, avoidance of legal permits and taxes and privacy concerns urgently need to be addressed in this fast developing field [7].

Only a few studies have conducted sustainability assessments of sharing organisations $[11,24,25]$. To evaluate the sustainability of sharing organisations, we must first understand how they create economic, environmental and social value [26] but very few studies have attempted this [25], partly due to a lack of useful tools to evaluate sustainability profile of sharing organisations [12].

\subsection{Sustainable Value Creation: Developing an Analytical Framework}

A business model describes "the rationale of how an organization creates, delivers and captures value" [15]. Conventional frameworks for business model analysis, such as Richardson's Business Model Framework [27] and Osterwalder \& Pigneur's Business Model Canvas [15], typically overlook the environmental and social dimensions of sustainable value creation [13]. Emerging research suggests considering the sustainability aspects [28] when analysing value provided by different business models [29] but currently there is no widely accepted framework. To address this, we have developed a framework in which the nine building blocks of the Business Model Canvas [15] are integrated with Richardson's framework [27] of value proposition, value creation \& delivery and value capture (Table 1). Value capture has been layered into economic, social and environmental value, as found in Joyce \& Paquin's [29] Triple-Layered-Business Model Canvas.

Table 1. Analytical Framework for Sustainable Value Creation.

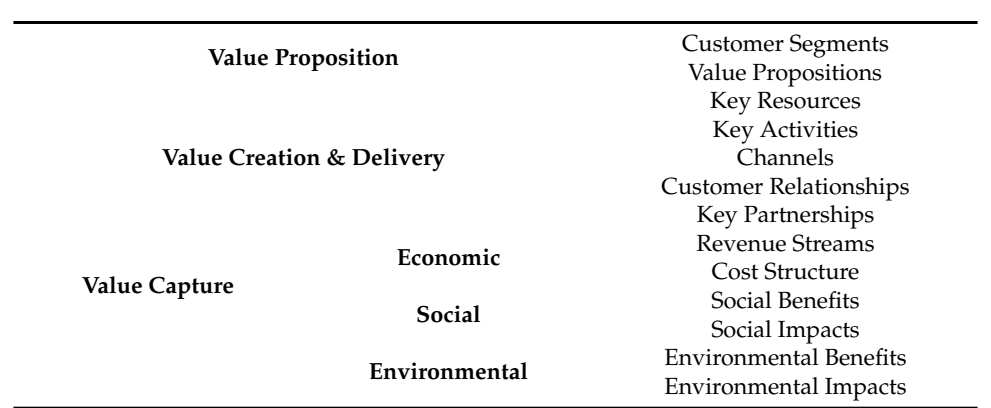

Source: Authors' own elaboration, adapted from Richardson [27], Osterwalder \& Pigneur [15] and Joyce \& Paquin [29]. 
The result is a simplified business model framework that enables a balanced analysis of sustainable value creation by sharing organisations, which we employ in our analysis of bicycle sharing organisations in Barcelona.

\subsection{Value Created by Bicycle Sharing Organisations}

The European Commission defines bicycle sharing as a "self-service, short-term, one-way capable bicycle rental offer in public spaces, for several target groups, with network characteristics" [30]. This definition makes a clear distinction between bicycle sharing systems (BSS) and traditional bicycle rental, though it appears to relate more to large-scale public schemes rather than smaller, private bicycle sharing operators. Interestingly, it does not emphasise sharing. This indicates that the purpose of BSS is not primarily to optimise the use of under-utilised resources or to facilitate social interaction but rather to provide a new form of flexible mobility.

BSS have evolved since the 1960s. The first generation, known as 'free bicycle' systems, were regular bicycles-painted in a distinct colour and distributed throughout the city, unlocked and free for public use-typically operated by environmental groups and non-profits [31,32]. However, these systems experienced frequent theft, vandalism and confiscation by the police [32]. The second generation of BSS featured secured parking and coin-deposits but the low deposit fees and user anonymity were still conducive to theft [32]. The third generation of BSS, now considered state-of-the-art, is characterised by a distinguishable design (e.g., colour, construction, advertisement) and technology-enabled docking stations using smart cards, apps or Radio Frequency Identification (RFID) to identify users [32]. The first example of this type of scheme was Velo'v in Lyon, France, launched in 2005 [31]. Today, over 1724 cities worldwide have bicycle sharing schemes, with a total of 18,243,900 bicycles in use [33]. Fourth-generation BSS is now on the horizon: demand-responsive, multi-modal systems integrated with public transport systems, with features like electric bicycles, touchscreen kiosks and GPS tracking [32].

Studies on bicycle sharing cover environmental [34] and social aspects [35], user motivations [36,37] and the impact of sharing behaviour on user innovativeness [38], the role of bike sharing in the total mobility system [39] and the role of values and ethics in the adoption of bike sharing systems [40]. We found only a handful of papers that explore the sustainability of bicycle sharing business models [41,42]. Unlike previous literature, our study applies the lens of institutionalism to a specific city context, to unveil the regulatory, normative and cognitive factors that shape the evolution of bicycle sharing in cities (Section 2.3).

\subsubsection{Value Proposition}

Bicycle sharing systems are thought to have many functional, environmental and social benefits. For users, they remove the costs of ownership, including storage, protection from theft and maintenance [43]. The main target groups of urban BSS are daily commuters and tourists [44]. For cities, they offer flexible mobility, reduce congestion and act as a 'first/last-mile' connection to strengthen public transport [32,39]. They encourage reducing fuel use and emissions, they can improve health and raise environmental awareness [32]. However, there is no significant evidence that bicycle sharing replaces the use of motorised vehicles [45].

\subsubsection{Value Creation and Delivery}

On average, bicycle sharing systems provide 15 bicycles and 1.5 stations per 10000 inhabitants [44]. Most offer a 24/7 service, although some, such as in Barcelona, close overnight. Typically, it is mandatory to register to use the service and registration entails a small fee or a deposit [44].

Bicycles can be accessed using an access card, code, key or via a person in charge. The bicycles typically feature a distinct and robust design to minimise vandalism, deter theft and ease maintenance. They are usually one-size-fits-all, which can also limit accessibility for children, elderly or disabled people. Often, the bicycles feature advertising space for the organisation itself or its sponsors. The majority of urban bicycle sharing systems in Europe have a fixed docking system or a built-in lock 
on the bicycles. Most European BSS are located in the most densely populated urban areas, with access to a docking station approximately every $300 \mathrm{~m}$ [44].

The systems are operated using special software providing registration, rental, information, customer data management and payment functions. The back-end of the system manages station monitoring, redistribution planning, defect management, customer data management and billing. The organisations are often accompanied by an app providing real-time information on nearby bicycles and stations, service updates, registration options, advertising and more. Usually, this is part of a wider communications strategy utilising a variety of channels, such as advertisements, websites, newsletters, social media, apps and/or customer service centres. BSS are often integrated within the city's public transport system, either physically at metro and bus stations or within the IT system providing functions such as intermodal routing and/or enabling access to all modes of public transport, including bicycle sharing, via the same access card.

A key part of the operations of municipal BSS is redistribution of the bicycles within the city to maintain a consistent service and meet local demand. This is especially the case in hilly coastal cities like Barcelona, where bicycles are more frequently used for downhill trips and need to be redistributed uphill. The positive environmental impact from the use of bicycles may therefore be cancelled out by the emissions of redistribution vehicles, given that they are not powered by biofuels or renewably generated electricity.

There are several different configurations of bicycle sharing business models, shown in Table 2.

Table 2. Bicycle sharing business models.

\begin{tabular}{|c|c|c|}
\hline Provider & Operating Model & Revenue Streams \\
\hline Advertising Companies & $\begin{array}{l}\text { Outdoor advertising or street furniture } \\
\text { companies, such as JCDecaux and Clear } \\
\text { Channel, provide BSS in exchange for public } \\
\text { advertising space. The bicycles themselves are } \\
\text { also used as advertising space. }\end{array}$ & $\begin{array}{c}\text { Advertising revenues (city street furniture, } \\
\text { billboards, bicycles and docking stations) } \\
\text { Usage fees }\end{array}$ \\
\hline Public Transport Agencies & $\begin{array}{l}\text { Together with the public authorities, the local } \\
\text { public transport agency provides BSS to } \\
\text { complement the public transportation network. }\end{array}$ & $\begin{array}{c}\text { Government subsidies } \\
\text { Usage fees } \\
\text { Advertising on bicycles and docking stations } \\
\text { Municipal funding }\end{array}$ \\
\hline Local Government & $\begin{array}{l}\text { BSS directly designed and operated by the local } \\
\text { government or by a contracted operator. }\end{array}$ & $\begin{array}{c}\text { Usage fees } \\
\text { Parking enforcement, congestion charges } \\
\text { Sponsorship } \\
\text { Advertising on bicycles and docking stations } \\
\text { Usage fees }\end{array}$ \\
\hline For-Profit & $\begin{array}{l}\text { Privately owned and operated BSS with } \\
\text { minimal government involvement }\end{array}$ & $\begin{array}{c}\text { Sponsorship } \\
\text { Advertising on bicycles and bicycle sharing } \\
\text { stations }\end{array}$ \\
\hline Non-Profit & $\begin{array}{l}\text { BSS operate under the support of public } \\
\text { agencies or councils }\end{array}$ & $\begin{array}{c}\text { Public-private } \\
\text { partnership funding } \\
\text { Usage fees } \\
\text { Bank loans } \\
\text { Local funding Donations }\end{array}$ \\
\hline
\end{tabular}

Sources: Shaheen et al. [32]; Cohen \& Kietzman [46].

\subsubsection{Sustainable Value Capture}

\section{Economic}

The main costs of the system are related to the initial investment and operating costs, such as infrastructure, implementation and running costs. In large-scale systems such as that in Barcelona, implementation of an electronic docking scheme can cost from EUR 2500 to EUR 3000 per bicycle. Running costs in large systems range from EUR 1500 to EUR 2500 per bicycle per year, entailing (from highest to lowest share of cost) redistribution of bicycles, bicycle maintenance, station maintenance, operating the back-end system, administration and replacements of bicycles and stations [44].

The main sources of finance for BSS come from registration and usage charges paid by the users. Charges are designed to encourage daily short-term use, such as by offering the first $30 \mathrm{~min}$ for free before applying an exponentially increasing charge up to a daily maximum amount or charging a fine 
when a certain limit is exceeded. An alternative model is a constant charge per time unit up to a less expensive daily maximum. Fees are also levied for unreturned or damaged bicycles.

Most municipal BSS are subsidised because revenues are not sufficient to cover the investment and running costs. Other means of financing are advertising and sponsorships.

Social

A recent study has found that the 12 major BSS in Europe provide health benefits-from an increase in physical activity--which greatly outweigh the risks of increased exposure to air pollution and road traffic fatalities. If $100 \%$ of bicycle sharing trips in these cities replaced car trips, an average of 73 deaths could be avoided per year [47].

\section{Environmental}

Bicycle sharing has raised bicycle modal share in European cities with previously low rates of cycling by up to $1.5 \%$ and has improved facilities for cycling. It has also increased the use of public transport by providing a first/last-mile solution. The BSS in Lyon saved the equivalent of 18,600,000 pounds of carbon dioxide emissions between 2005 and 2009 [31].

However, the environmental benefits of bicycle sharing appear to be primarily attributed to the promotion of cycling, rather than from reduced resource use due to sharing. Research has shown that members of BSS are more likely to own private bicycles than non-members [45]. There is also no evidence that bicycle sharing replaces car use; rather, it has been shown that the majority of bicycle sharing users are substituting from other sustainable modes of transport, such as walking or public transportation [45].

\subsection{Institutionalisation Strategies}

Voytenko \& Mont [48] argue that innovative business models in the sharing economy, such as those of bicycle sharing illustrated above, can catalyse broader institutional change, by:

- motivating other organisations to consider new ways of delivering value in order to remain competitive against newcomers;

- changing social norms and values; and

- driving change in regulatory, economic and other institutional frameworks.

We use insights from institutionalism to understand the ways in which bicycle sharing systems interact with their environment to institutionalise themselves. This is the first step to understanding how they might catalyse broader institutional change.

Institutions are the "rules of the game in society" [49], which cause organisational structures and behaviours to become increasingly similar over time [50]. Institutions can be understood as "the humanly devised constraints that shape human interaction" [49]. They define what behaviours are considered socially acceptable and credible or legitimate [51]. Institutions can take the form of rules and laws (regulative institutions), social values and norms (normative institutions) or cultural frameworks (cultural-cognitive institutions) [52]. These are known as the 'three pillars' of institutionalisation.

Over time, institutions can develop complex interdependencies that lock-in certain behaviours in an organisational field. An organisational field is made up of "key suppliers, resources and product consumers, regulatory agencies and other organizations that produce similar services or products" [50]. Depending on the level of institutionalisation in an organisational field, Scott's [52] three pillars may be strongly aligned, unevenly distributed or entirely misaligned-providing low to high opportunity for institutional change [53].

Highly institutionalised organisational fields are characterised by "clearly defined leading actors, a coherent discourse, structures of cooperation and domination, sets of accepted norms and stable interorganizational relationships" [54]. External events or 'exogenous jolts', such as an environmental crisis, technological disruption, regulatory change or social upheaval often reveal 
disparities between institutions [55]. This provides the opportunity for certain actors to question them [54,56-58]. Those actors, 'institutional entrepreneurs', may take actions to "create, disrupt or maintain" institutions, despite being embedded in themselves [59]. In this study, BSS are considered institutional entrepreneurs because they represent the sharing economy that is disrupting traditional business models.

Faced with the "liability of newness" [51], institutional entrepreneurs engage in various strategies to achieve legitimacy for themselves and their activities. These strategies are referred to in the literature as "institutional work" [60]. Lawrence \& Suddaby [60] identify ten strategies for institutionalisation employed by institutional entrepreneurs. The strategies are categorised as regulatory, normative and cultural-cognitive work, depending on the types of institutions they target.

Mont, Voytenko Palgan and Zvolska [17] have proposed a framework adapted from Lawrence \& Suddaby [60] to reflect strategies for institutionalisation used specifically by sharing organisations (Table 3). As a very new framework, it has not yet been tested empirically. One of the aims of our study is to test this framework.

Table 3. Analytical framework for institutionalisation strategies of sharing organisations.

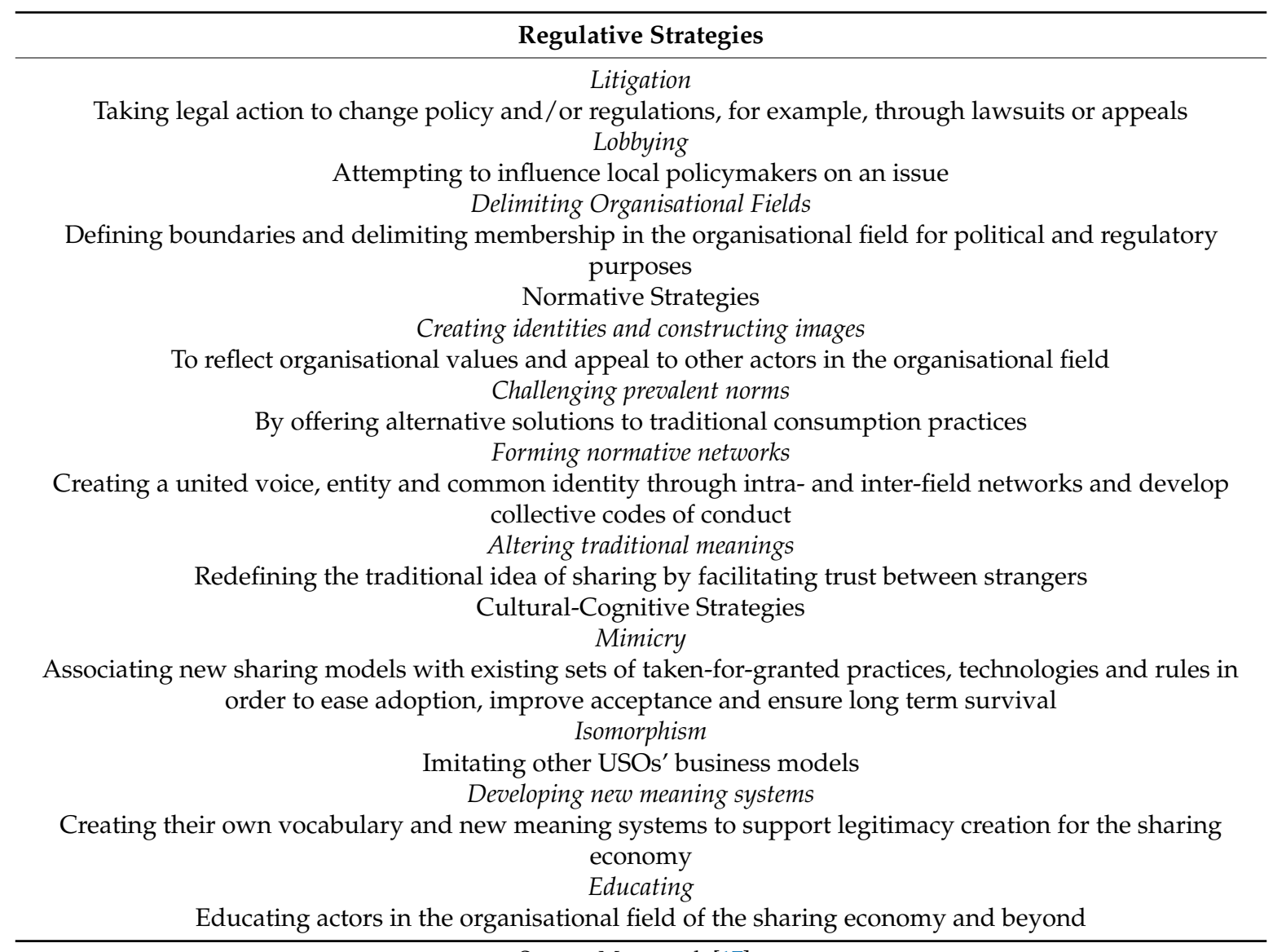

Source: Mont et al. [17].

\section{Methods}

In order to address aims and research questions, an instrumental case study design [61,62] was applied to three bicycle sharing systems in Barcelona. Rich data was collected from a variety of primary and secondary sources, including a three-week field study in Barcelona in July 2018. The research was conducted in three stages, using different sources and procedures, as outlined in Table 4. 
Table 4. Outline of Research Stages.

\begin{tabular}{|c|c|c|}
\hline Research Stage & Procedures & Sources \\
\hline \multirow{7}{*}{ Preliminary Research } & \multirow{4}{*}{ Identification and selection of cases } & Websites \\
\hline & & News articles \\
\hline & & Social media \\
\hline & & Academic journals \\
\hline & \multirow{3}{*}{ b) Preparation of interviews } & Grey literature \\
\hline & & Websites \\
\hline & & Press articles \\
\hline \multirow{5}{*}{ Fieldwork } & \multirow{4}{*}{ a) Data collection in Barcelona } & Interviews (semi-structured) \\
\hline & & Field notes \\
\hline & & Photographs \\
\hline & & Flyers, brochures, printed marketing materials \\
\hline & \multirow{2}{*}{ a) Interpretation of collected data } & $\begin{array}{l}\text { Analytical framework for Sustainable Value Creation } \\
\text { (Authors' own) }\end{array}$ \\
\hline \multirow[t]{7}{*}{ Analysis } & & $\begin{array}{c}\text { Analytical framework for institutionalisation strategies } \\
\text { of sharing organisations }\end{array}$ \\
\hline & & Academic journals \\
\hline & & Websites \\
\hline & b) Supplementation of information & News articles \\
\hline & where required & Reports \\
\hline & & Social media \\
\hline & & Press articles \\
\hline
\end{tabular}

Source: own elaboration.

This study identified three active BSS in Barcelona, specified in Table 5. The case studies represent the entire bicycle sharing market in the city. The organisations were contacted by e-mail and telephone, using contact details provided on their company websites. This initial enquiry was forwarded within the respective organisations until a suitable research partner was found-a top-level manager, in all three cases.

The preparation of interview questions was guided by the two analytical frameworks. However, the questions were formulated to avoid explicitly referring to theoretical concepts [63]. The questions revolved around the history and development of the organisations, operations, funding, challenges, target audience, strategic partnerships, promotional strategies and the rationale for their organisation. The interview guide was used in an open and contextual fashion to encourage interviewees to answer questions freely [64]. A sample of the questions is provided in the Appendix A.

The interviews were arranged and scheduled prior to arrival in Barcelona and all interviewees were made aware of the purpose and subject of the study. The interviews were conducted in English and lasted up to $1 \mathrm{~h}$. All interviews were transcribed and provided to the interviewees for fact-checking.

Table 5. Selected Case Study Subjects.

\begin{tabular}{|c|c|c|c|}
\hline Organisation & Description & Interviewee & Date \\
\hline Bicing & $\begin{array}{l}\text { Public bicycle scheme provided by Barcelona } \\
\text { City Council. It is one of Europe's first and most } \\
\text { successful large-scale public bicycle schemes. }\end{array}$ & $\begin{array}{l}\text { Advisor to the } \\
\text { Mobility Councillor }\end{array}$ & 13 July 2018 \\
\hline Donkey Republic & $\begin{array}{l}\text { Copenhagen-based for-profit bike-sharing } \\
\text { company and the first private operator to } \\
\text { successfully launch in Barcelona. }\end{array}$ & $\begin{array}{l}\text { Country Manager for } \\
\text { Spain }\end{array}$ & 2 August 2018 \\
\hline Scoot Networks & $\begin{array}{l}\text { A for-profit shared electric mobility company } \\
\text { from San Francisco, which launched its first } \\
\text { European operations with a fleet of e-bikes and } \\
\text { e-scooters in Barcelona in July } 2018 \text {. }\end{array}$ & $\begin{array}{l}\text { Vice President for } \\
\text { European Market } \\
\text { Expansion }\end{array}$ & 30 July 2018 \\
\hline
\end{tabular}

Interview data was supplemented by recording impressions of the bicycle sharing services in the city in the form of extensive field notes and photographs. Where available, secondary sources such as printed marketing materials were collected for further background information and to understand how the organisations framed their sustainability strategies and presented their business models and institutionalisation strategies. 
Although this study mainly focused on the perspective of the bicycle sharing organisations themselves, other representatives of the cycling culture in Barcelona were interviewed informally to obtain a wider picture of the views on bicycle sharing by organisational actors in the city. These interviewees included the president of the Bicyclists Club of Catalunya (BACC) and grassroots cycling activists working in local bike kitchens (DIY bicycle repair workshops).

To answer the first research question, the data collected in stages 1 and 2 was analysed using the Value Creation Framework. The interview data was triangulated with secondary data from company websites, press articles and social media to ensure greater validity. To answer the second research question, the framework on institutional strategies was used. Codes were pre-defined according to the framework and applied using NVivo software.

\section{Limitations}

To provide an in-depth and specific analysis of value creation and institutionalisation strategies in a specific institutional context, the scope of this study was limited to bicycle sharing organisations in Barcelona. This means that the findings are specific to the situation in Barcelona and are not generalisable unless further tested in cross-case or cross-country analyses. However, the methodology used in this article could be used as a blueprint for such future studies.

Rooted in business model literature and institutionalism, the focus of this study was on the organisations themselves, so user perspectives of the bicycle sharing services were not collected systematically. Informal conversations with bicycle users helped give the researchers a more holistic picture of the situation in Barcelona but were not used in the final analysis. The authors sought to collect both the organisations' perspectives and those of the City Council as an institutional actor. However, as Bicing is a public service, the interviewee for the Bicing service as well as Barcelona Mobility Council was the same individual. The interviewee was highly knowledgeable about all aspects of bicycle sharing in Barcelona but a subjective bias toward the public Bicing service cannot be excluded.

Finally, language barriers may have limited the extent of data collected and the interpretation of results. Several of the required sources and materials were available only in Spanish or Catalan, which are not spoken by the researchers. Interviews were conducted in English. The researchers controlled this limitation by preparing translations for interview questions in advance, using translation software and consulting native speakers in order to interpret Spanish or Catalan language data.

\section{Sustainable Value Creation and Institutionalisation Strategies in Barcelona}

There are three main providers of bicycle sharing services in Barcelona: Bicing, which is the public bicycle sharing service provided by the city council and two private providers, Donkey Republic and Scoot. In this section we analyse these organisations' value provision and institutionalisation strategies.

\subsection{Value Creation by Bicycle Sharing Systems}

The following section analyses the value proposition, value creation \& delivery and value capture processes and activities of the three BSS.

\subsubsection{Bicing}

Background

The public bicycle sharing system Bicing was launched in Barcelona in 2007 by the mayor Jordi Hereu to "take the next step towards prioritising [Barcelona's] sustainable policy and the promotion of public transport within the city centre" [65]. It was a huge success, overshooting all forecasted usage rates and catalysing an expansion of cycling culture and infrastructure in the city [66]. By the end of its first year, the service had nearly six times more subscribers than expected, totalling 100,000 subscriptions [66]. 
Normative pressures from other cities in Europe encouraged Barcelona's politicians to take measures to promote urban bicycle use. As Álvaro Nicolas Loscos, Advisor to the Mobility Councillor, explained: "Our politicians travelled to other parts of Europe, mainly in the northern countries and saw that the use of bicycles was popular. Their plan was not to make a huge development of the cycling infrastructure but they started to introduce the first bicycle lanes about 25 years ago." [67] Then, once the first third-generation bicycle sharing system had been implemented in Lyon, they recognised an opportunity.

As illustrated in Figure 1, bicycle trips in the city increased by 82\% in 2007 compared to 2006 [68]. This was not least due to the expansion of the Bicing system, which normalised the use of bicycles on the streets and sidewalks of Barcelona.

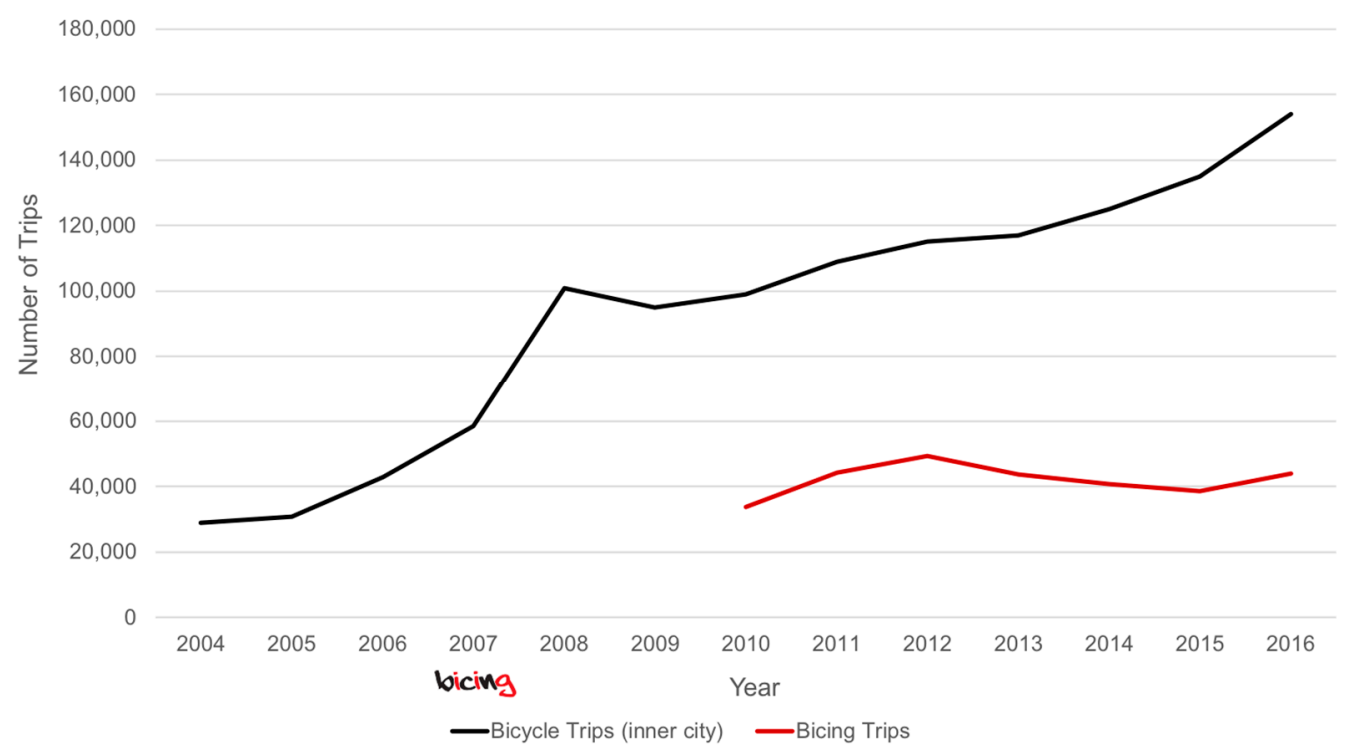

Figure 1. Inner-City Bicycle Trips in Barcelona, 2004-2016. Source: Authors' elaboration, based on data from Ajuntament de Barcelona [68-70] (Comparable data for trips made using the Bicing service was only available from 2010 onwards.).

Value Proposition

The objective of the Bicing system is to offer the bicycle as a daily choice for travel and to promote sustainable mobility at an affordable price [71]. As a service provided by the municipality, Bicing is in a better position to be integrated with the public transport network and provide a subsidised, low-cost service.

"Because it's a public service and it's the municipality that provides the system, it's different from many other bicycle sharing systems offered by a private company" explained the Advisor to the Mobility Councillor. "The quality of the service that they can offer is going to be very different from Bicing. I mean, we spent a lot of money on it, it's expensive, it's everywhere ... it's very difficult for them to achieve that. (... ) Therefore, what I think is going to happen, is that those kinds of systems are going to be used more by visitors rather than by locals who already have access to Bicing" [67].

The Bicing service is only available to registered citizens of Barcelona. The subscription registration process takes two weeks, intentionally hindering tourists and visitors from using the system in order to protect local bicycle rental shops [44,67]. Bicing is mainly used to commute to work or study or for running personal errands [66].

The key benefits that users perceive of the system are the avoidance of maintenance costs, affordability and not having to worry about theft and vandalism [72], which supports the findings in earlier studies on motivations for users to join BSS. However, the Bicing service cannot offer the same door-to-door flexibility and assurance of availability as owning a private bicycle. The lack of 
possibilities to take children on the bicycles is also perceived by many people in Barcelona as a barrier to using the service [72].

\section{Value Creation and Delivery}

Bicing has 6000 bicycles and 420 stations available for its 100,000+ subscribers [73]. A pilot project in 2014 added 300 electric bicycles at 46 stations [71]. Docking stations are strategically placed within a 300-m catchment area throughout the city centre. The bicycles have a distinct and robust design to deter theft and vandalism. The user is randomly assigned a bicycle by the system and can unlock it using an RFID key card.

To keep the system running smoothly, Bicing redistributes bicycles between stations to meet peak demand. This is a complex logistical process, carried out primarily using a fleet of petrol-powered trucks. Bicycles are also maintained and repaired on a daily basis. The system employs approximately 174 workers, with roles ranging from management and administration, maintenance and redistribution [74]. Bicing communicates with its users via its website, social media channels (Facebook and Twitter), app and customer service hotline.

BSS in most large cities are managed via a single contract with an outdoor advertisement company, which provides the bicycle sharing operations and service in exchange for public advertising space. In Barcelona, however, the City finances Bicing from its public advertising contract but has a separate contract with the municipal services provider, B:SM, which organises the operations of the Bicing service [67]. By keeping these contracts separate, Barcelona avoids advertising pollution and can remain more flexible with its choice of suppliers [75].

Between 2007 and 2018, B:SM commissioned the outdoor advertising company Clear Channel to provide the Bicing service [65]. However, a new 10-year operating contract worth EUR 149.6 million came into force in November 2018 with a new provider: a temporary joint venture between Cespa, Spain's leading industrial waste management company and the global bicycle sharing provider PBSC [76]. The entire system is being upgraded with a new fleet of bicycles and e-bicycles, improved docking stations and additional services such as advance bookings of up to five minutes, as well as different tariff systems for annual and occasional use [77]. The relocation trucks will be replaced with a fleet of electric vehicles to reduce $\mathrm{CO}_{2}$ emissions [78].

\section{Value Capture: Economic}

The Bicing system cost EUR 15 million to implement [44] and annual running costs amount to EUR 18 million [67]. The revenues from user fees are approximately EUR 4.2 million per year, covering about $23 \%$ of the costs of running the system [71]. Previously, an advertising sponsorship from Vodafone from March 2014 financed a further $8 \%$ but the contract ended without renewal in March 2018 [71,79]. The system runs at a deficit: the remaining $69 \%$ is funded by the municipality from its public advertising revenues $[67,71]$.

An annual subscription to the Bicing service currently costs EUR 47.16. In order to incentivise short trips, the first $30 \mathrm{~min}$ of each trip are free and each additional half hour (up to a maximum of two hours) is charged at EUR 0.74. If two hours are exceeded, a penalty fee is charged at EUR 4.49 per hour. The fees for e-bicycles are slightly higher. If a bicycle (mechanical or electrical) has not been returned after $24 \mathrm{~h}$, a fee of EUR 150 is charged.

Value Capture: Social

As a public service provided by the municipality, Bicing is intended to provide a social benefit to its citizens by improving public health and enabling last-mile access to public transport. "Everything started as a matter of social justice and equity, because we should provide public transport for the people who didn't have money to buy their own cars. In our society, it's a recognized right to have access to the city. So, we should provide a way to get everywhere, somehow. ( ... ) And also [because of] the positive impact it has on people to use the bicycle and walk on a daily basis," stated the Advisor to the Mobility Councillor [67]. 
A recent study found that bicycle commuters in Barcelona benefited from up to two more hours of physical activity per week than those who commuted by public transport, car or motorcycle [80]. A representative study of the population of Barcelona also found perceived stress to be reduced among commuters using the Bicing service or a private bicycle [81]. Furthermore, it has been estimated that the Bicing system saves 12.28 lives per year due to the health benefits of cycling, which greatly outweigh the risks from air pollution and road accidents [82].

In 2016, Bicing made up 27\% of bicycle trips in Barcelona (see Figure 1). There is no conclusive data indicating whether non-bicycle users who are introduced to cycling via the Bicing service later become users of private bicycles. However, while the share of Bicing trips dropped by $23 \%$ in 2016 compared to 2013, urban cycling in Barcelona has been experiencing a continuous increase (see Figure 1). This indicates that more people are using private bicycles, probably an effect of the infrastructure and regulatory improvements initiated by the huge initial uptake of the Bicing service.

However, as with any business, the Bicing system also has negative social externalities. These include accidents, conflicts with pedestrians or drivers of motor vehicles, operational faults, time lost looking for a bicycle or free parking slot, broken or vandalised bicycles and increased congestion from the redistribution trucks [75]. Another issue is the opportunity cost for car users who lose public car parking spaces when docking stations are placed on the road [75], although a reduction of motorised vehicles in the city is one of the intentions of the Bicing programme.

Value Capture: Environmental

While Bicing began with a social purpose, its rationale is becoming more environmental in light of the Paris Agreement and political developments. According to the interviewee, "the reasons why we are trying to promote more sustainable mobility have changed a lot. Now we are worried about other impacts of the current mobility system-not just on the world from the $\mathrm{CO}_{2}$ emissions but also because of where the petrol is coming from and the political tensions that it's causing" [67]. It has been estimated that the potential reduction in $\mathrm{CO}_{2}$ emissions from cycling instead of car travel represented $0.9 \%$ of emissions from all types of motor vehicles in Barcelona in 2009 [82].

Despite its environmental cause, the Bicing system also comes with negative environmental externalities, such as noise, air pollution and $\mathrm{CO}_{2}$ emissions from the trucks used to redistribute the bicycles [75]. The new 10-year contract will improve the environmental balance of the service with an entirely electric redistribution fleet [78].

\subsubsection{Donkey Republic}

\section{Background}

Donkey Republic started in 2005 in Copenhagen as a Kickstarter campaign for peer-to-peer (P2P) bicycle rental [83]. Today, it is a global bicycle sharing platform allowing users to access a bicycle in cities across the world using a single app. Donkey Republic was the first private bicycle sharing provider in Barcelona, having launched there in 2016.

\section{Value Proposition}

The Donkey Republic app allows users to easily access a bicycle in cities across the world without the hassle of docking stations, cash payments, ID cards, deposits or limited opening hours [84]. Bicycles are available for both short trips (starting at $30 \mathrm{~min}$ ) and long rental periods (up to 14 days), offering "a convenient middle-way between bicycle ownership and pure bicycle sharing" that appeals to both locals and tourists [85]. Bicycles can be parked flexibly within the city at pre-defined drop-off points.

Value Creation and Delivery

To provide a localised service in every city, Donkey Republic operates as a franchise or joint venture in partnership with local bicycle operators, called 'Bicycle Owners'. The Bicycle Owners have 
ownership of the hardware (bicycles and special electronic locks) and are responsible for distribution, maintenance and local marketing. Donkey Republic provides the software, customer support, data analysis, online marketing and acquisitions operations [86]. Donkey Republic has been operating in Barcelona since 2016 and recently acquired the local Bike Owner company [87]. Together, they started out with less than 30 bicycles; today, there are 500 'Donkeys' available for rent in Barcelona [87].

Donkey Republic bicycles are distinguishable by their bright orange colour and robust design. The Donkey Republic operating system consists of two components: a smartphone application and an electronic ring lock. The Donkey Republic 'Rider App' allows users to "create an account, find and rent bicycles, unlock and lock their rented bicycle, switch bicycles, extend and end a rental or sign up for special memberships available locally" [88]. Users can either rent bicycles using a pay-per-use scheme or sign up for a local membership which offers free or discounted rides for a fixed monthly fee. These memberships are a recent feature of the Donkey Republic service and are only available to Spanish residents, as a local bank card is required in order to subscribe.

The Donkey Republic 'Owner App' is connected to an online dashboard to help the Bike Owners manage their fleet by keeping an overview of rentals, parking locations, usage data, revenues and other statistics. Bluetooth-enabled electronic ring locks, placed on all bicycles in the fleet, assign bicycles to geo-registered pick-up and drop-off locations [88].

Donkey Republic requires that bicycles be parked using public bicycle racks within designated drop-off locations called 'Hubs'. Hubs are geo-located GPS coordinates. Donkey Republic uses geofencing technology [89] to ensure that users can only end their rental within a fixed radius (e.g., $10 \mathrm{~m}$ ) of a Hub. Donkey Republic controls the number of bicycles that can be parked at each Hub, determining a maximum capacity depending on the available space and, in some cases, in coordination with the city authorities [90]. This helps to avoid cluttering public space and incorrect parking of bicycles [91].

Operations typically require at least two full-time employees (operations management and marketing/sales) and one mechanic per 300 bicycles [86]. Each bicycle in the fleet is checked on a weekly basis [91]. Incorrectly parked bicycles and bicycles that have been parked outside a Hub must be relocated. This is done using a bicycle trailer to avoid $\mathrm{CO}_{2}$ emissions [92]. The company is also exploring the possibility of using electric tricycles ("e-trikes") for easier relocation in narrow streets and uphill [92].

\section{Value Capture: Economic}

Donkey Republic originally launched as a Kickstarter campaign, raising EUR 40000 [93]. In 2016, the company received an investment of EUR 1.5 million to start its global expansion [93]. Revenues from local operations are split 80/20 between the operator and Donkey Republic [86]. Operators typically earn a monthly average of EUR 40-50 per bicycle [94], generating an estimated monthly revenue of EUR 20,000-25,000 for the Donkey Republic fleet of 500 bicycles in Barcelona.

Rental fees depend on the duration of the rental and are calculated using a pre-defined price index, starting with the base price of EUR 12 for a 24-h rental period. The rates decrease over time, incentivising day rental. Monthly memberships are also available, offering cheaper rental rates for occasional and regular users. An additional EUR 5 fee is charged if the booked rental period is exceeded. A EUR 250 fee is charged for missing bicycles. A stolen bicycle can cost the user up to EUR 300 if they did not purchase a EUR 2 theft insurance at the time of booking. If bicycles are not returned to a designated drop-off point, a relocation fee of EUR 10 is charged. If bicycles are returned more than $10 \mathrm{~km}$ away from the closest drop-off location, a EUR 50 fee is charged.

Setting up a Donkey Republic bicycle sharing business requires an initial investment of at least EUR 200 000. This can either be split 50/50 between the Donkey Republic headquarters and the Bike Owner in a joint venture or covered entirely by the Bike Owner in a full ownership model. Running costs include relocation of the bicycles and maintenance. Bicycle maintenance typically costs operators EUR 2.50 per bicycle per month (excluding personnel costs) [95]. This amounts to an estimated cost of EUR 1250 per month for the Donkey Republic fleet in Barcelona. 
Value Capture: Social

The Donkey Republic bicycle sharing service creates the same social value as the Bicing service through health benefits, reduced car congestion and air pollution and improved connectivity throughout the city. In addition, it serves a social group that is excluded from the Bicing service--visitors to Barcelona.

Similar to Bicing, social externalities of the Donkey Republic service include accidents, conflicts with pedestrians or drivers of motor vehicles, operational faults and broken or vandalised bicycles. Since the Donkey Republic system relies on public bicycle parking infrastructure for its pick-up and drop-off points, conflicts have arisen where citizens feel that their public space is being used for private commercial benefit. It is also considered by some as an unfair advantage against bicycle rental shops, who must have a license and pay rent for their commercial space [96]. These conflicts indicate the current lack of regulative institutions in this area. By introducing a licensing system, the City could help private operators such as Donkey Republic achieve public legitimacy-or inhibit them with high fees.

Value Capture: Environmental

Like Bicing, the Donkey Republic service contributes to lowering $\mathrm{CO}_{2}$ emissions from transport by offering a fossil-free alternative. However, unlike Bicing, Donkey Republic keeps its service emissions-free by using non-motorised vehicles to redistribute falsely parked bicycles. This is enabled by Donkey Republic having far simpler redistribution logistics compared to Bicing because of its smaller fleet size.

\subsubsection{Scoot Networks}

\section{Background}

Scoot is a shared electric vehicle provider from San Francisco. They opened their first European headquarters in Barcelona in July 2018. Traditionally providing electric scooters, they made the decision to expand their fleet to include electric bicycles especially for their launch in Barcelona. Scoot's mission is to provide "Electric Vehicles for Everyone" with their multi-modal offer [97].

Value Proposition

The Scoot e-bicycle system has a convenient dockless system and offers fast, easy travel by electric bicycle. Bicycles can be parked anywhere within the central city. The Scoot service is intended only for those who live or work in the Barcelona area [98].

\section{Value Creation and Delivery}

Scoot launched in Barcelona with a fleet of 1000 electric bicycles. The e-bicycles, which can reach a maximum speed of $25 \mathrm{~km} / \mathrm{h}$, feature a robust, anti-theft construction with a custom design by a local artist of Barcelona. The bicycles are run via electric battery packs, which are charged at the Scoot offices and exchanged via an electric Scooter [99].

The Scoot service can be accessed through the Scoot Networks app. Users must have a Spanish bank card to download the app, making it difficult for tourists from abroad to access. The e-bicycles can be unlocked using the app and parked at any public bicycle rack within the designated "Scoot Area," which covers most central areas of the city. Incorrectly parked bicycles are manually moved and bicycles are repaired on a daily basis [99].

Scoot owns its entire operations in Barcelona. The Barcelona branch office started with a team of 20 employees and plans to grow to 60 employees by the end of 2018 [100]. 
Value Capture: Economic

The project cost for Scoot's launch in Barcelona is estimated at EUR 5 million [101]. The business operations in Barcelona are financed by investors and user fees [99]. The Scoot service has a very simple and straightforward pricing system at EUR 0.10 per minute.

Value Capture: Social

Scoot offers the same social benefits as its counterparts Bicing and Donkey Republic, such as improved health and last-mile mobility. By providing electric mobility, it may also appeal to user groups with less physical fitness who may be discouraged from using mechanical bicycles. However, like Donkey Republic, Scoot is facing public criticism for its use of public infrastructure for commercial activity.

\section{Value Capture: Environmental}

Scoot claims that their electric vehicles have $25 \%$ less environmental impact than combustion vehicles [100]. According to Scoot, 300,000 $\mathrm{kg}$ of $\mathrm{CO}_{2}$ were saved by its users in the first three weeks of its operations in Barcelona [102]. The environmental impact from redistribution is very low, as incorrectly parked bicycles are moved manually [99].

\subsubsection{Summary}

Table 6 summarises the results to demonstrate the value created by the business models of the three bicycle sharing organisations in Barcelona, including social and environmental value capture dimensions.

Table 6. Overview of sustainable value creation of bicycle sharing business models.

\begin{tabular}{|c|c|c|c|}
\hline Organisation & Bicing & Donkey Republic & Scoot \\
\hline \multirow{10}{*}{ Value Creation \& Delivery } & docking system & dockless & dockless \\
\hline & mechanical and electric & mechanical only & electric only \\
\hline & locals only & locals and visitors & locals only \\
\hline & cheap & fixed drop-off points & drop-off anywhere in \\
\hline & PT integration & throughout the city & designated area \\
\hline & 6000 bicycles & 500 bicycles & 1000 e-bicycles \\
\hline & 300 e-bicycles & smartphone app & smartphone app \\
\hline & $\begin{array}{l}\text { RFID key card } \\
\text { external operator }\end{array}$ & external operator & own operations \\
\hline & $23 \%$ user fees, $8 \%$ & $100 \%$ user fees $(80 / 20$ & $100 \%$ user fees \\
\hline & sponsorship, $69 \%$ subsidies & $\begin{array}{l}\text { revenue split } \\
\text { operator/Donkev Republic) }\end{array}$ & \\
\hline \multirow{5}{*}{ Social + benefits - costs } & + health & $\begin{array}{l}\text { operator / Donkey Kepubin) } \\
\text { + health }\end{array}$ & \\
\hline & + reduced congestion+ & + reduced congestion & + reduced congestion \\
\hline & last-mile mobility & + last-mile mobility & + last-mile mobility \\
\hline & $\begin{array}{l}\text { - conflicts with pedestrians } \\
\text { and drivers }\end{array}$ & $\begin{array}{c}\text { + inclusive (locals and } \\
\text { visitors) }\end{array}$ & $\begin{array}{c}\text { + electric bicycles increase } \\
\text { inclusivity }\end{array}$ \\
\hline & & $\begin{array}{l}\text { - commercial use of public } \\
\text { infrastructure }\end{array}$ & $\begin{array}{l}\text { - commercial use of public } \\
\text { infrastructure }\end{array}$ \\
\hline Environmental & + emission-free travel & + emission-free travel & + emission-free travel \\
\hline+ benefits- costs & $\begin{array}{l}\text { + less air pollution } \\
-\mathrm{CO}_{2} \text { emissions from } \\
\text { redistribution vehicles }\end{array}$ & + less air pollution & + less air pollution \\
\hline
\end{tabular}

Source: Author's own elaboration.

\subsection{Institutionalisation Strategies of Bicycle Sharing Systems in Barcelona}

As illustrated in the previous section, bicycle sharing has become relatively institutionalised as a form of urban mobility in Barcelona but there still are some obstacles to be overcome. Over ten years have passed since the introduction of Bicing, which has enabled the city to iron out initial challenges with the system and to improve the service. It is evident that Barcelona's public bicycle sharing system changed the role of the bicycle in the city's mobility mix and in the minds of its citizens. The cycling culture and infrastructure that developed as a result of Bicing has attracted international private providers of bicycle sharing services in more recent years. However, the lack of regulative institutions 
to promote or control bicycle sharing providers indicates that the organisational field of bicycle sharing is still developing.

The following sections illustrate the regulative, normative and cultural-cognitive strategies employed by the case organisations to influence the institutionalisation process.

\subsubsection{Regulative Strategies}

Regulatory work includes litigation, lobbying and delimiting membership in the organisational field for political and regulatory purposes [17].

As yet, there is no regulatory framework for bicycle sharing in Barcelona, due to the novelty of the industry. "For the moment, there is no legal framework for [bicycle sharing operators] to operate in the public space," explained the Advisor to the Mobility Councillor [67] "but there are not many of them and we are not having many troubles like in other cities. If we can put norms onto the use of these kinds of bicycles in the public space, then we would like to have like a limited number, to see that nothing goes out of control."

Therefore, there has been no need for litigation. The Donkey Republic Country Manager for Spain explained: "We were in contact with the city council from the very beginning but they cannot regulate something until it has become a problem-you cannot make a license for something that does not yet exist. ( ... ) Originally, we were the only ones even using the bike racks but now bicycle ownership is rising and people feel that the racks belong to them."

An open process for creating a regulatory framework for bike-sharing in Barcelona is now underway. "The legal framework has to come into place before the end of this year" stated the Advisor to the Mobility Councillor [67]. It will apply to all shared vehicles, such as cars, scooters and bikes [87]. For shared bicycles, it will specify where and how the bikes should be parked, insurance requirements, minimum/maximum fleet size, annual tax, minimum usage rates, minimum service level and more [87]. It is also likely to involve a pricey permit system [87].

\section{Lobbying}

Lobbying refers to the efforts by sharing organisations to influence local policymakers on an issue [17]. The development of the new regulatory framework represents an opportunity for the existing bicycle sharing operators to apply regulative strategies in an attempt to influence the outcome in their favour.

Collaborating with other stakeholders, both Donkey Republic and Scoot are members of the working group developing the new regulatory framework with the city council [67]. Both companies pride themselves on their track record of close collaboration with local authorities to provide efficient solutions that serve the needs of the city and its residents $[87,99]$. According to the Vice President for European Market Development at Scoot, the company would be open to subsidising bicycle parking spaces if the city planned to add more [99].

\section{Delimiting Organisational Fields}

Delimiting organisational fields refers to "defining boundaries and delimiting membership in the organisational field for political and regulatory purposes" [17].

Donkey Republic emphasises that it is a system "designed in Europe, for the needs of European cities," clearly differentiating itself from Chinese and Asian operators that have overwhelmed other cities [85]. It highlights that the Donkey Republic system enables an efficient use of public space and the ability for city authorities to monitor and control the operations [85], thereby appealing to regulative institutions to gain legitimacy even in a largely unregulated field.

There is evidence that private bicycle sharing operators are intentionally trying to disassociate bicycle sharing from being a service primarily for tourists, due to the public disillusionment with mass tourism in the city [21]. "They see those kinds of bicycles as very linked to tourists and they think there are too many tourists" explained the Advisor to the Mobility Councillor [67]. Donkey Republic has recently introduced a membership scheme providing a more attractive proposition for locals, which could also 
be interpreted as a strategy by the company to address this negative cognitive association as a tourists' service. For similar reasons, Scoot has chosen to provide its service to locals only: "Scoot wants to work closely with the city council and, as there have been a lot of issues with mass tourism in the city, it is intended only as a solution for locals right now" [99].

\subsubsection{Normative Strategies}

Normative strategies for institutionalisation can be identified in all of the case studies, though there are differences between how they are used by private actors compared to the City Council as a public provider.

\section{Creating Identities and Constructing Images}

This strategy refers to the identities that sharing organisations create for themselves to increase their appeal to other actors in the organisational field [17]. All three cases define their relationship to the sharing economy in different ways, to appeal to their most important stakeholders.

Bicing defines itself as "urban transport based on bicycle sharing" [103]. It is clear that the City Council primarily intends Bicing to be seen as an extension to the city's public transport system. It is also interesting to note that they specifically mention sharing. They highlight all three types of sustainable value created by the system-economic, social and environmental: "a simple, practical and sustainable service that you can use in your journeys around the city. To go where you want and when you want, without smoke or noise" [103]. Bicing is also clear at defining what it is not: "[it is] not a public bicycle rental system for tourist or recreational use" [103], directly addressing the common misconception that public BSS are primarily for tourists. We interpret this as an effort to appeal to other actors in the field: to reassure local bicycle rental businesses that they are not trying to compete with them and to affirm residents that the public money funding the system is being reinvested for their own benefit.

Donkey Republic recognises the different needs of its various stakeholders and addresses them individually on its website, with dedicated landing pages for riders, bicycle owners and cities. To its riders, it describes itself as a "24/7 Bicycle Rental" service [84]. There is no mention of sharing. We interpret this as a strategy by the company to differentiate itself from the negative connotations of bicycle sharing created by controversial mass providers such as Obicycle and Ofo [89]. Interestingly, there is also no mention of an environmental cause; the key benefits that Donkey Republic communicates are simplicity and convenience. This indicates that it is strategically preferable to compete with traditional field actors on a functionality basis, rather than on environmental benefits. It is clear that the website is targeted at tourists, as it is provided entirely in English and includes information such as "Where do Barcelona Locals go?" [104].

In contrast, on its 'Bicycle Owners' landing page, Donkey Republic no longer refers to itself as a bicycle rental service but explicitly identifies itself as a "bicycle-share" platform. It emphasises the profitability of the Bicycle sharing business with statistics and figures [105]. For city authorities, Donkey Republic also uses the term 'bicycle-share'. Donkey Republic aims to be an efficient, sustainable urban mobility solution: "Our goal is to make urban transportation simple and more sustainable, as well as to make city life in general better for everyone" [85].

Scoot clearly positions itself within the sharing economy and associates this with innovative technology like electric mobility and digital solutions: "Our scoots are shared, electric, smartphone-activated vehicles." [106]. By defining themselves as a sharing, tech-enabled, electric mobility organisation, they position themselves as an innovator. Scoot attempts to relate to their target audience by creating an image of themselves as "city slickers, gearheads, tree huggers and teachers" [106]. Scoot makes a conscious effort to be seen as locality-specific. The colourful design of the bicycles was created by a Barcelonian artist and they announced their launch with: "After many months of work, we can finally proclaim ourselves authentic Barcelonians and we are more than proud 
of it!" [107]. Scoot founder Michael Keating said about the Barcelona launch: "It's meant to be for locals. Not just a joy-riding thing" [108].

\section{Challenging Prevalent Norms}

Sharing organisations often directly challenge traditional consumption norms with the alternative solutions they offer [17]. It is clear that all three bicycle sharing providers present their service as an alternative solution to conventional motorised vehicles.

The Advisor to the Mobility Council explained that, with Bicing, "we are introducing a new variable to the mobility policies" and trying to "constrain ( ... ) or make more difficult the use of cars" [67]. The interviewee from Donkey Republic stated that "Barcelona has tens of thousands of noisy dirty scooters. I am proud to be part of changing that to silent, friendly bicycle use" [87]. And according to the interviewee from Scoot, "in Europe, most cities have thousands of private gas-burning cars. By providing multi-modal networks of shared electric vehicles and through collaborative planning with cities, Scoot can transform urban mobility to make cities more liveable and enjoyable" [109].

However, these statements show that the normative institution these businesses are trying to challenge is not necessarily that of private ownership but rather the institutions that have turned cities into car-based societies. Instead, sharing is presented as a stepping stone or an enabler to challenging those institutions by making emissions-free mobility more accessible, rather than the ultimate goal.

\section{Forming Normative Networks}

Sharing organisations might seek to create a united voice and common identity through intra- and inter-field networks [17]. While Bicing is not part of any networks, the private providers in this study have either joined other networks or formed their own to form a united voice for the sharing economy.

"Recently, bicycle and scooter shares have taken the initiative to form an association to improve their ability to communicate their importance for the city to the city council and public" [87] explained the Country Manager for Spain at Donkey Republic. Scoot is also a part of this association, which does not have an official name yet.

At industry level, Donkey Republic is a member of the European Cyclists' Federation (ECF) and the UK bicycle sharing association BicyclePlus. Scoot has joined the digital economy association Adigital España, which offers training, legal advice and market research and has a special focus on the sharing economy $[99,110]$.

In these cases, forming networks appears to be a strategy preferred by private providers. This is probably due to the more peripheral social position of private operators, so joining forces can strengthen their voice and bargaining power.

\section{Altering Traditional Meanings}

In the context of the sharing economy, the word 'sharing' has developed to have many different meanings. Sharing organisations often use normative strategies to redefine the traditional idea of sharing as being a familial practice to something that can also take place between strangers. The private bicycle sharing providers in the study both define what sharing means to their organisation.

Donkey Republic explains its role in the sharing economy as follows: "Local operators ( . . ) can set up bicycles in a city to be shared among visitors and locals" [93]. On its company website, Scoot states that "Scoot is about sharing: sharing vehicles, sharing data, sharing space" [97]. It adds, "we share much more than our vehicles; we share our city and its roads, our way of life and our desire to create cities that are more friendly for their citizens" [107].

Since the BSS in this study are not peer-to-peer (P2P), their definition of sharing is less about creating trust between sharing but rather about the access and inclusiveness created by sharing. 


\subsubsection{Cultural-cognitive strategies}

To gain legitimacy, BSS utilise cultural-cognitive strategies such as mimicry, isomorphism, developing new meaning systems and educating. These strategies are evident among all three case studies but appear to be more prominent and intentional amongst the private operators.

Mimicry

Mimicry occurs when new models of sharing are associated with conventional institutions to ease their adoption and improve their acceptance [17]. Examples of mimicry are primarily evident amongst the private sharing operators.

Donkey Republic originally started out as a Kickstarter for a P2P service, where individual bicycle owners could place an electronic lock on their bicycle and rent it out to others. The interviewee for Donkey Republic stated that he had recognised the potential of this idea but also that it would be difficult to scale it. "I told them: your idea is cool but I think you shouldn't do P2P, you should use my rental business instead" [87]. He recognised that, by tapping into established bicycle-rental businesses, Donkey Republic could professionalise and grow its sharing concept.

Scoot tries to ease adoption and improve acceptance by associating its service with existing mobility systems and rules: "Current transportation infrastructure needs support through flexible networks of shared electric vehicles. Free-float networks achieve this by complementing traditional transportation networks with electric scooters, e-bicycles and electric cars" [97].

However, these examples of mimicry are not particularly strong, indicating that this strategy is not used intentionally by the case organisations.

Isomorphism

Bicycle sharing systems engage in isomorphism when they mimic the business models of other successful sharing organisations in order to support their own legitimacy [17]. All three cases show a degree of isomorphism.

For example, Bicing was inspired by the public bicycle sharing system in Lyon: "Our politicians (... ) saw the system working in Lyon, one of the first in the world. They very quickly took it on as an idea and launched the Bicing process in Barcelona six months later" [67].

In its Kickstarter days, Donkey Republic had actually named their product (the smartphone application connected to an electronic lock) 'AirDonkey' to associate it with the successful accommodation sharing service Airbnb [83]. They described their company as combining "the simplicity of Uber and the sharing economy of Airbnb" [111]. The idea was also referred to as "Uber for Bicycles" [112]. However, no evidence was found that this strategy was used specifically in Barcelona.

Similarly, Scoot founder Michael Keating often describes Scoot as "Zipcar for e-scooters" [113]. In the download centre for their smartphone app, they explain that "Scoot works in a similar way to carsharing apps" [114].

Developing New Meaning Systems

This strategy of institutional work refers to the creation of an own vocabulary and new meaning systems to create legitimacy for sharing organisations [17].

Both Bicing and Donkey Republic have created their own vocabulary. The success of the Bicing system unintentionally created a new meaning: the term 'Bicing' became a common synonym for public bicycle organisations in Spain [115].

By referring to its bicycles as "Donkeys," Donkey Republic has created its own vocabulary that alludes to a distant past, before the introduction of motorised vehicles: "Once, a donkey was the most accessible, dependable and commonplace means of transportation. Nowadays (... ) the humble bicycle is taking the role of its hoofed ancestor as a convenient and pragmatic device of urban 
mobility" [116]. While the meaning itself does not relate to sharing, it is a meaning associated with its bicycles and the quiet revolution they aim to create.

\section{Educating}

Educating refers to efforts to spread knowledge and understanding of the sharing economy [17]. In the bicycle sharing case studies, educating seems to be performed mainly by private operators and directed toward the city. Operators try to provide recommendations (and influence) city authorities in matters concerning how to effectively regulate BSS. One example is Donkey Republic's article "4 principles for a sustainable bike-share" [91]. The Scoot blog also promotes the importance of multi-modality for sustainable urban transport. In a developing and unregulated area such as shared mobility, educating appears to be a prime tool for positioning a company as a credible actor in the field and influencing regulators.

\section{Discussion}

By employing a business model framework that includes not only economic but also environmental and social dimensions, to understand how value is created, delivered, captured by bicycle sharing organisations, this study has gone beyond the mainstream use of business model frameworks in organisational literature $[15,26]$. Inspired by recent publications $[13,29]$, the study extends the investigation of sustainable value creation further than in the extant literature [25,27], by discussing not only value captured in the form of social and environmental benefits but also value destroyed through negative impacts.

The analysis of sustainable value creation by BSS in Barcelona supports the general academic consensus that the social and environmental value created by BSS clearly outweighs their impacts [66, $75,82]$. The public bicycle sharing system, Bicing, provides an integrated first/last-mile solution to extend the reach of the public transport network, thereby contributing to improved social justice and inclusion for the local population. However, the organisation offers its services only to locals, thereby excluding a significantly large social group in Barcelona: its 30 million annual visitors. Furthermore, Bicing shows the greatest potential for environmental value creation through increased bicycle use through the sheer scale and popularity of the system but much of this value is destroyed by the use of fossil-fuel vehicles to fulfil its complex bicycle redistribution logistics.

In contrast, the private operators Donkey Republic and Scoot use emissions-free methods to redistribute their bicycles but have a higher perceived social impact due to their use of public bicycle racks for commercial gain. These two issues will be addressed by the new electric redistribution vehicles planned for Bicing in 2019 and the upcoming regulatory framework for the use of public space by shared vehicle providers. This shows that these externalities are not unavoidable consequences of these business models but can be controlled by appropriate organisational and institutional measures.

A limitation of the framework is that it does not specifically distinguish the actors for which value is provided or identify who captures value. There is emerging literature on triadic business models that distinguish between customers, peer service providers and platform providers $[117,118]$ and can serve as inspiration for further elaboration of Sustainable Value Creation by sharing organisations.

The analysis of institutionalisation strategies of the bicycle sharing systems confirms the underlying assumption that, as an organisational field becomes institutionalised, organisations become increasingly similar [50]. The trend of public BSS in Europe inspired the establishment of Barcelona's own public bicycle system, Bicing. This was a way for the city to create and support a cycling culture in the city. Indeed, Bicing soon became a synonym for bicycle sharing in Spain, thereby helping to further institutionalise bicycle sharing not only on the municipal level but also on a national level. The normative and cultural-cognitive institutions created by Barcelona's newfound cycling culture attracted new, private providers to the market.

While the lack of regulatory institutions for BSS was initially an enabling factor for these providers, it is evolving into an obstacle for achieving cultural-cognitive legitimacy among residents, who view 
their use of public space for commercial gain as unlawful and associate private bicycle sharing operators with the problems of mass tourism. Private bicycle sharing providers engage in lobbying and delimitation of organisational fields in an attempt to influence the outcomes of the regulatory framework in their favour.

Bicycle sharing systems were found to address different stakeholders strategically by constructing different identities and images of themselves. Interestingly, associating their business with the sharing economy appears to be favourable for a commercial audience rather than for customers. Sharing, a feature that unites the three case studies and is a key aspect of the sharing economy, did not play a central role in the institutionalisation strategies of the case organisations and the term was used rather anecdotally by the interviewees. This is probably because BSS see themselves more as mobility organisations than as sharing organisations.

\section{Conclusions}

The causes of our unsustainable rates of consumption are deeply embedded in the regulative, normative and cultural-cognitive institutions that govern our daily actions. However, individual actors are also able to create, maintain and even disrupt these complex institutions, as demonstrated by recent developments in the sharing economy. This article set out to explore the value created by bicycle sharing organisations and the strategies they use to institutionalise themselves. We applied two analytical frameworks to three BSS in Barcelona. The first framework was developed from recent business model literature to analyse the types of value created by BSS. Our findings supported claims from the literature that the social and environmental value of these organisations outweigh their negative impacts $[45,66,82]$. Finally, opportunities for increasing that value through operational and institutional strategies were identified.

The framework for institutionalisation strategies revealed that the BSS in Barcelona all employ regulative, normative and cultural-cognitive strategies to influence the development of their organisational field. The case studies offer a rich description of case organisations, their successes and struggles, which might be useful for bicycle sharing entrepreneurs or even for municipalities who aim to better understand the institutionalisation strategies of BSS. While the data indicate that there is also no single pathway for the institutionalisation of BSS, they do appear to share a common conviction: that the bicycle is a tool for institutional change towards a more just, healthy and sustainable society.

The scope of the study was limited to the bicycle sharing market in a city that is relatively new to bicycle sharing and has not yet experienced the same challenges as many other cities in Europe and China [89,119]. This enabled the authors to provide empirical evidence of value creation and institutionalisation strategies within an explicit organisational, geographical and institutional context. Therefore, the findings are not intended to be generalisable to other cities but rather to provide insight into a specific institutional context in a crucial moment of its development. If the institutional strategies employed by the City Council and bicycle sharing organisations in Barcelona are successful, they might be spared some of the growing pains of bicycle sharing experienced in other cities.

Furthermore, the analysis underlined the applicability and usefulness of two novel frameworks, contributing to the extant business management literature. The sustainable value creation framework could be further developed in future studies by specifying value captured by the three actors in the T-models of the sharing economy: platform, peer users and peer providers [117,118].

The study provided the first empirical test of the framework for institutional strategies of sharing organisations [17]. It confirmed that institutionalism is an appropriate approach for understanding the development of organisational fields in the sharing economy. Value could be added to this framework by developing a method for identifying and analysing the greater institutional context within which the sharing organisations operate. Insights from literature on institutional logics might prove useful for that purpose [18]. Finally, future studies might also seek to use both frameworks as a blueprint for cross-case or cross-country comparisons. 
Author Contributions: Conceptualisation, J.W. and O.M.; methodology, J.W.; validation, J.W. and O.M.; formal analysis, J.W.; investigation, J.W.; data curation, J.W.; writing-original draft preparation, J.W.; writing-review and editing, J.W. and O.M.; visualisation, J.W.; supervision, O.M.; project administration, J.W.; funding acquisition, O.M.

Funding: This research is part of the project Urban Reconomy, which is funded by a Swedish Research Council for sustainable development (Formas), grant number 211-2014-1440.

Acknowledgments: Kind thanks are due to the interviewees from Barcelona Mobility Council, Donkey Republic and Scoot Networks for their participation in this research; and to Vera Chudnikova for her comments on the draft of this paper.

Conflicts of Interest: The authors declare no conflict of interest. The funders had no role in the design of the study; in the collection, analyses or interpretation of data; in the writing of the manuscript or in the decision to publish the results.

\section{Appendix A}

\section{Sample interview questions for bicycle sharing organisations}

1. Can you tell me a bit about the history of your business?

a. Why did you decide to provide bike-sharing services in Barcelona?

b. Did you face any challenges or obstacles in starting your business in Barcelona?

2. Please explain to me briefly how your bicycle sharing system works.
a. How many bicycles are there in your fleet?
b. What are your user policies for parking bicycles?
c. How do you relocate incorrectly parked bicycles?
d. What do you do with damaged bicycles?

3. Who is your target customer in Barcelona?

4. What benefits does your service offer compared to other bicycle sharing services in the city?

5. Did you require any specific permits from the city to start your operations in Barcelona?

6. Do you receive any support (financial, technical, promotional ... ) from the city council?

7. Are you a part of any industry networks or associations?

8. What channels do you use to promote your business?

9. Do you see your business as part of the 'sharing economy'?

\section{References and Notes}

1. Global Footprint Network World Ecological Footprint. Available online: https:/ /www.footprintnetwork. org/our-work/ecological-footprint/ (accessed on 14 June 2018).

2. United Nations Responsible Consumption \& Production: Why It Matters. Available online: https://www.un.org/sustainabledevelopment/wp-content/uploads/2016/08/16-00055L_Why-itMatters_Goal-12_Consumption_2p.pdf (accessed on 14 June 2018).

3. United Nations. World Population Prospects: The 2017 Revision, Key Findings and Advance Tables; Department of Economic and Social Affairs, Population Division: New York, NY, USA, 2017.

4. Edelman. 2018 Edelman Trust Barometer Global Report; Edelman Trust Barometer Annual Global Study; Edelman: Chicaga, IL, USA, 2018.

5. Gerzema, J.; Kotler, P.; D'Antonio, M. Spend Shift: How the Post-Crisis Values Revolution Is Changing the Way We Buy, Sell, and Live; Jossey-Bass: San Francisco, CA, USA, 2014.

6. Botsman, R. The Sharing Economy Lacks a Shared Definition. Available online: https:/ / www.fastcompany. com/3022028/the-sharing-economy-lacks-a-shared-definition (accessed on 8 July 2018).

7. Mont, O.; Whalen, K.; Nussholz, J. Sustainable innovation in business models: Celebrated but not interrogated. In Sustainable Innovation (Upcoming); Boons, F., McMeekin, A., Eds.; Routledge: London, UK, 2019. 
8. Botsman, R.; Rogers, R. What's Mine Is Yours: The Rise of Collaborative Consumption; HarperBusiness: New York, NY, USA, 2010.

9. Stokes, K.; Clarence, E.; Anderson, L.; Rinne, A. Making Sense of the UK Collaborative Economy. Available online: https: / collaborativeeconomy.com/wp/wp-content/uploads/2015/04/making_sense_of_the_uk_ collaborative_economy_14.pdf (accessed on 22 January 2019).

10. Murillo, D.; Buckland, H.; Val, E. When the sharing economy becomes neoliberalism on steroids: Unravelling the controversies. Technol. Forecast. Soc. Chang. 2017, 125, 66-76. [CrossRef]

11. Daunorienè, A.; Drakšaitè, A.; Snieška, V.; Valodkienè, G. Evaluating sustainability of sharing economy business models. Procedia Soc. Behav. Sci. 2015, 213, 836-841. [CrossRef]

12. Plepys, A.; Singh, J. Challenges and research needs in evaluating sustainability impacts of sharing economy using input-output analysis. In A Research Agenda for Sustainable Consumption Governance; Mont, O., Ed.; Edward Elgar Publishing Ltd.: Cheltenham, UK; Northampton, MA, USA, 2019.

13. Cohen, B. Making Sense of the Many Business Models in the Sharing Economy. Available online: https:/ / www.fastcompany.com/3058203/making-sense-of-the-many-business-models-in-thesharing-economy (accessed on 29 May 2018).

14. Bocken, N.; Short, S.; Rana, P.; Evans, S. A value mapping tool for sustainable business modelling. Corp. Gov. Int. J. Bus. Soc. 2013, 13, 482-497. [CrossRef]

15. Osterwalder, A.; Pigneur, Y. Business Model Generation: A Handbook for Visionaries, Game Changers, and Challengers; Wiley: Hoboken, NJ, USA, 2010.

16. Mair, J.; Reischauer, G. Capturing the dynamics of the sharing economy: Institutional research on the plural forms and practices of sharing economy organizations. Technol. Forecast. Soc. Chang. 2017, 125, 11-20. [CrossRef]

17. Mont, O.; Voytenko Palgan, Y.; Zvolska, L. Towards an explanatory framework for institutionalisation processes of urban sharing organisations. In Proceedings of the Sustainable Consumption: Fostering Good Practices and Confronting the Challenges of the 21st Century; Copenhagen Business School: Copenhagen, Denmark, 2018; p. 13.

18. Grinevich, V.; Huber, F.; Karataş-Özkan, M.; Yavuz, Ç. Green entrepreneurship in the sharing economy: Utilising multiplicity of institutional logics. Small Bus. Econ. 2017. [CrossRef]

19. Zhang, N.; Sia, S.K.; Lee, G. Sharing Economy Disruption and the Quest for New Institutional Legitimacy. In Proceedings of the ICIS (International Conference on Information Systems), Seoul, Korea, 10-13 December 2017.

20. Menoyo, C.C. Urban commons: Lessons from Barcelona at the beginning of 21st century. Available online: https:/ / speakerdeck.com/ccamara/urban-commons-lessons-from-barcelona-at-the-beginning-of21st-century (accessed on 22 January 2019).

21. Russo, A.P.; Scarnato, A. "Barcelona in common": A new urban regime for the 21st-century tourist city? J. Urban Aff. 2018, 40, 455-474. [CrossRef]

22. Molas, M. Barcelona lidera el NO a l'economia col-laborativa capitalista. Recerca Revista de pensament i Anàlisi. Available online: http:/ / www.e-revistes.uji.es/index.php/recerca/article/view/2608 (accessed on 22 January 2019).

23. Miller, A.B.; Barcelona Crowdsourced Its Sharing Economy Policies. Can Other Cities Do the Same? Available online: https:/ / www.shareable.net/blog/barcelona-crowdsourced-its-sharing-economy-policies-can-othercities-do-the-same (accessed on 27 May 2018).

24. Frenken, K.; Schor, J. Putting the sharing economy into perspective. Environ. Innov. Soc. Transit. 2017, 23, 3-10. [CrossRef]

25. Voytenko Palgan, Y.; Zvolska, L.; Mont, O. Sustainability framings of accommodation sharing. Environ. Innov. Soc. Transit. 2017, 23, 70-83. [CrossRef]

26. Porter, M.E.; Kramer, M.R. Creating shared value. Harv. Bus. Rev. 2011, 89, 62-77.

27. Richardson, J. The business model: An integrative framework for strategy execution. Strateg. Chang. 2008, 17, 133-144. [CrossRef]

28. Elkington, J. 25 Years ago i coined the phrase "Triple bottom line." Here's why it's time to rethink it. Harvard Business Review, 201825 June 2018.

29. Joyce, A.; Paquin, R.L. The triple layered business model canvas: A tool to design more sustainable business models. J. Clean. Prod. 2016, 135, 1474-1486. [CrossRef] 
30. Intelligent Energy Europe Project Fact Sheet-Optimising Bike Sharing in European Cities (OBIS). 2009. Available online: https:/ / ec.europa.eu/energy/intelligent/projects/en/printpdf/projects/obis (accessed on 21 January 2019).

31. DeMaio, P. Bike-sharing: History, impacts, models of provision, and future. J. Public Transp. 2009, 12, 41-56. [CrossRef]

32. Shaheen, S.; Guzman, S.; Zhang, H. Bikesharing in Europe, the Americas, and Asia: Past, present, and future. Transp. Res. Rec. 2010, 2143, 159-167. [CrossRef]

33. Meddin, R.; DeMaio, P. Legend-In Operation—Beginning August 2018. Available online: https:/ / www.google. $\mathrm{com} / \mathrm{maps} / \mathrm{d} /$ viewer?mid=1UxYw9YrwT_R3SGsktJU3D-2GpMU\&hl=en (accessed on 3 August 2018).

34. Qiu, L.-Y.; He, L.-Y. Bike sharing and the economy, the environment, and health-related externalities. Sustainability 2018, 10, 1145. [CrossRef]

35. Spinney, J.; Lin, W.-I. Are you being shared? Mobility, data and social relations in Shanghai's Public Bike Sharing 2.0 sector. Appl. Mobilities 2018, 3, 66-83. [CrossRef]

36. Lan, J.; Ma, Y.; Zhu, D.; Mangalagiu, D.; Thornton, T. Enabling value co-creation in the sharing economy: The case of Mobike. Sustainability 2017, 9, 1504. [CrossRef]

37. Lou, L.; Koh, J. Factors Affecting User Participation in Sharing Economy: The Case of Commercial Bike Sharing Service in China; (2018). The 22nd Pacific Asia Conference on Information Systems (PACIS 2018) Proceedings. 169. Available online: https:/ / aisel.aisnet.org/pacis2018/169 (accessed on 21 January 2019).

38. Pieper, T.; Tietze, F.; Schultz, C.; Herstatt, C.; Pieper, T.; Tietze, F.; Schultz, C.; Herstatt, C. To share or not to share-Exploring the impact of sharing behavior on user innovativeness. In Proceedings of the Academy of Management, Atlanta, GA, USA, 4-8 August 2017.

39. Zhang, L.; Zhang, J.; Duan, Z.; Bryde, D. Sustainable bike-sharing systems: Characteristics and commonalities across cases in urban China. J. Clean. Prod. 2015, 97, 124-133. [CrossRef]

40. Yin, J.; Qian, L.; Singhapakdi, A. Sharing sustainability: How values and ethics matter in consumers' adoption of public bicycle-sharing scheme. J. Bus. Ethics 2018, 149, 313-332. [CrossRef]

41. Barquet, A.P.; Seidel, J.; Buchert, T.; Galeitzke, M.; Neugebauer, S.; Oertwig, N.; Rozenfeld, H.; Seliger, G. Sustainable Product Service Systems-From concept creation to the detailing of a business model for a bicycle sharing system in Berlin. Procedia CIRP 2016, 40, 524-529. [CrossRef]

42. van Waes, A.; Farla, J.; Frenken, K.; de Jong, J.P.J.; Raven, R. Business model innovation and socio-technical transitions. A new prospective framework with an application to bike sharing. J. Clean. Prod. 2018, 195, 1300-1312. [CrossRef]

43. Mátrai, T.; Tóth, J. Comparative assessment of public bike sharing systems. Transp. Res. Procedia 2016, 14, 2344-2351. [CrossRef]

44. OBIS. Optimising Bike Sharing in European Cities-A Handbook. 2011, p. 90. Available online: mobilityworkspace.eu/wp-content/uploads/OBIS_Handbook_EN.pdf (accessed on 21 January 2019).

45. Fishman, E.; Washington, S.; Haworth, N. Bike ahare: A synthesis of the literature. Transp. Rev. 2013, 33, 148-165. [CrossRef]

46. Cohen, B.; Kietzmann, J. Ride On! Mobility business models for the sharing economy. Organ. Environ. 2014, 27, 279-296. [CrossRef]

47. Otero, I.; Nieuwenhuijsen, M.J.; Rojas-Rueda, D. Health impacts of bike sharing systems in Europe. Environ. Int. 2018, 115, 387-394. [CrossRef] [PubMed]

48. Voytenko, Y.; Mont, O. Innovative value creation models for sustainable living. In Proceedings of the SCORAI Europe E InContext Workshop; SCORAI Europe: Rotterdam, The Netherlands, 2013; p. 360.

49. North, D.C. Institutions, Institutional Change, and Economic Performance; Cambridge University Press: Cambridge, UK; New York, NY, USA, 1990.

50. DiMaggio, P.J.; Powell, W. The iron cage revisited institutional isomorphism and collective rationality in organizational fields. In American Sociological Review; American Sociological Association. Sage Publications: Thousand Oaks, CA, USA, 1983; Volume 17, pp. 147-160.

51. Suchman, M.C. Managing legitimacy: Strategic and institutional approaches. Acad. Manag. Rev. 1995, 20, 571-610. [CrossRef]

52. Scott, W.R. Institutions and Organizations (Foundations for Organizational Science); SAGE: Thousand Oaks, CA, USA, 1995.

53. Scott, W.R. Institutions and Organizations: Ideas, Interests, and Identities; SAGE: Los Angeles, CA, USA, 2014. 
54. Maguire, S.; Hardy, C.; Lawrence, T.B. Institutional entrepreneurship in emerging fields: HIV/aids treatment advocacy in Canada. Acad. Manag. J. 2004, 47, 657-679.

55. Meyer, A.D. Adapting to environmental jolts. Adm. Sci. Q. 1982, 27, 515. [CrossRef] [PubMed]

56. Lawrence, T.B.; Suddaby, R.; Leca, B. Introduction: Theorizing and studying institutional work. In Institutional Work: Actors and Agency in Institutional Studies of Organizations; Cambridge University Press: Cambridge, UK; New York, NY, USA, 2009.

57. Holm, P. The dynamics of institutionalization: Transformation processes in Norwegian fisheries. Adm. Sci. Q. 1995, 40, 398. [CrossRef]

58. Schneiberg, M.; Lounsbury, M. Social movements and institutional analysis. In The SAGE Handbook of Organizational Institutionalism; Greenwood, R., Oliver, C., Sahlin, K., Suddaby, R., Eds.; SAGE: Los Angeles, CA, USA; London, UK, 2008.

59. DiMaggio, P.J. Interest and agency in institutional theory. In Institutional Entrepreneurship; The International Library of Entrepreneurship; Edward Elgar Publishing Limited: Cheltenham, UK, 1988.

60. Lawrence, T.B.; Suddaby, R. Institutions and institutional work. In The SAGE Handbook of Organization Studies; SAGE Publications Ltd.: London, UK, 2006; pp. 215-254.

61. Stake, R.E. The Art of Case Study Research; Sage Publications: Thousand Oaks, CA, USA, 1995.

62. Yin, R.K. Case Study Research: Design and Methods, 2nd ed.; Applied Social Research Methods Series; Sage Publications: Thousand Oaks, CA, USA, 1994; ISBN 978-0-8039-5662-9.

63. Hermanns, H. Interviewing as an activity. In A Companion to Qualitative Research; Flick, U., Kardorff, E., Steinke, I., Eds.; SAGE: London, UK, 2004; pp. 225-241.

64. Flick, U. An Introduction to Qualitative Research, 3rd ed.; Sage Publications: London, UK; Thousand Oaks, CA, USA, 2006; ISBN 978-1-4129-1145-0.

65. Scholtus, P. The TH Interview: Bicing, Barcelona's Bike Sharing System (Part 1: City Council). Available online: https: / / www.treehugger.com/culture/the-th-interview-bicing-barcelonaatms-bike-sharing-systempart-1-city-council.html (accessed on 28 May 2018).

66. Anaya, E. Are public bikes systems good for cycling? The view from Barcelona. In Proceedings of the Bicycle Politics Workshop, Lancaster, UK, 2010; p. 38. Available online: imperial.academia.edu/EstherAnaya (accessed on 21 August 2018).

67. Barcelona Mobility Council. Personal Interview with the Advisor to the Mobility Councillor at Barcelona City Council. 2018.

68. Ajuntament de Barcelona. Dades bàsiques de mobilitat 2007; Direcció de Serveis de Mobilitat: Barcelona, Spain, 2008; p. 119.

69. Ajuntament de Barcelona. Dades bàsiques de mobilitat 2013; Direcció de Serveis de Mobilitat: Barcelona, Spain, 2014; p. 17.

70. Ajuntament de Barcelona. Dades bàsiques de mobilitat_Informe 2016; Dades bàsiques de mobilitat; Àrea d'Ecologia, Urbanisme i Mobilitat: Barcelona, Spain, 2017; p. 44.

71. Loscos, ÁN. Present \& Future Bike Sharing Systems. Presented at the Moscow International Cycling Congress, Moscow, Russia, 1-14 April 2017.

72. Curto, A.; de Nazelle, A.; Donaire-Gonzalez, D.; Cole-Hunter, T.; Garcia-Aymerich, J.; Martínez, D.; Anaya, E.; Rodríguez, D.; Jerrett, M.; Nieuwenhuijsen, M.J. Private and public modes of bicycle commuting: A perspective on attitude and perception. Eur. J. Public Health 2016, 26, 717-723. [CrossRef]

73. Ajuntament de Barcelona Informació del sistema. Available online: https://www.bicing.cat/ca/content/ informaci\%C3\%B3-del-sistema (accessed on 21 August 2018).

74. Blanchar, C. El nuevo contrato del Bicing no prevé mejoras en las condiciones laborales. El País, 2017, 11 July. Available online: https://elpais.com/ccaa/2017/07/11/catalunya/1499773144_177197.html (accessed on 15 July 2018).

75. Anaya, E.; Bea, M.; Cost-benefit Evaluation of Bicing. Workshop 6: The Renaissance of Cycling; 2009. Available online: www.epomm.eu/ecomm2009/6_bea.pdf (accessed on 15 July 2018).

76. Blanchar, C. Cespa gana el contrato del Bicing a Clear Channel. El País, 2017, 1 December. Available online: https:/ / elpais.com/ccaa/2017/12/01/catalunya/1512135485_926526.html (accessed on 17 July 2018).

77. Ajuntament de Barcelona El nuevo contrato del Bicing amplia los servicios. Available online: http:// mobilitat.ajuntament.barcelona.cat/es/noticia/el-nuevo-contrato-del-bicing-amplia-los-servicios (accessed on 20 August 2018). 
78. Barcelona Mobility Council. Personal Communication with the Advisor to the Mobility Councillor at Barcelona City Council. 2018.

79. Soto, A. El Bicing de Barcelona se queda sin patrocinador. Available online: https://www.elperiodico.com/ es/barcelona/20180813/bicing-barcelona-sin-patrocinador-6987647 (accessed on 21 August 2018).

80. Donaire-Gonzalez, D.; de Nazelle, A.; Cole-Hunter, T.; Curto, A.; Rodriguez, D.A.; Mendez, M.A.; Garcia-Aymerich, J.; Basagaña, X.; Ambros, A.; Jerrett, M.; et al. The added benefit of bicycle commuting on the regular amount of physical activity performed. Am. J. Prev. Med. 2015, 49, 842-849. [CrossRef]

81. Avila-Palencia, I.; de Nazelle, A.; Cole-Hunter, T.; Donaire-Gonzalez, D.; Jerrett, M.; Rodriguez, D.A.; Nieuwenhuijsen, M.J. The relationship between bicycle commuting and perceived stress: A cross-sectional study. BMJ Open 2017, 7, e013542. [CrossRef] [PubMed]

82. Rojas-Rueda, D.; de Nazelle, A.; Tainio, M.; Nieuwenhuijsen, M.J. The health risks and benefits of cycling in urban environments compared with car use: Health impact assessment study. BMJ 2011, 343, d4521. [CrossRef] [PubMed]

83. Ovacik, E. AirDonkey: Earn Money on Your Bike. Available online: https://www.kickstarter.com/projects / 2084861579/airdonkey-join-the-bike-sharing-revolution (accessed on 5 September 2018).

84. Donkey Republic. Bike Rental 24/7. Available online: https://www.donkey.bike/ (accessed on 4 September 2018).

85. Donkey Republic. The Donkey Republic Bike-Share System. Available online: https://cities.donkey.bike/ donkey-republic-bike-share-system/ (accessed on 2 September 2018).

86. Donkey Republic. Bike-share Operations. Available online: https://owners.donkey.bike/bike-shareoperations/ (accessed on 2 August 2018).

87. Donkey Republic. Personal Communication with the Country Manager for Spain at Donkey Republic. 2018.

88. Donkey Republic. The Technology Behind Our System. Available online: https://cities.donkey.bike/donkeyrepublic-bike-share-technology/ (accessed on 2 September 2018).

89. Fratila, S. 2017-The Year Bike Sharing Went Crazy. Available online: https://www.donkey.bike/2017-bikesharing-went-crazy/ (accessed on 2 September 2018).

90. Donkey Republic. The Hub-Centric Model. Available online: https:/ / cities.donkey.bike/bike_share_hubcentric-model/ (accessed on 2 September 2018).

91. Donkey Republic. 4 principles for a Sustainable Bike Share. Available online: https://cities.donkey.bike/4principles-sustainable-bike-share/ (accessed on 2 September 2018).

92. Donkey Republic. E-Mail Communication with the Country Manager for Spain at Donkey Republic. 2018.

93. Posetti, B. Donkey Republic Company Profile. Available online: https:/ /www.donkey.bike/wp-content/ uploads/2017/05/EN_Donkey_Republic_Company_Profile.pdf (accessed on 2 September 2018).

94. Donkey Republic. What Is Expected Earnings per Bicycle? Available online: http://help.donkey.bike/hc/ en-us/articles/212801969-What-is-expected-earnings-per-bicycle- (accessed on 31 August 2018).

95. Donkey Republic. The Bike-Share Business. Available online: https://owners.donkey.bike/bike-sharebusiness / (accessed on 2 September 2018).

96. Bicitours Bicicletas de alquiler en los aparcamientos públicos de Barcelona: I Associació Bicitours Barcelona. Available online: http:/ / www.bicitoursbarcelona.org/noticias/la-invasion-de-bicicletas-de-alquiler-enlos-aparcamientos-publicos-de-barcelona/ (accessed on 1 September 2018).

97. Scoot Networks Multi-modal Networks \& Electric Vehicles for Everyone. Available online: https://scoot.co/ stories / multi-modal-networks-collaborative-planning/ (accessed on 1 September 2018).

98. Scoot Networks Membership Qualifications. Available online: http://scootbarcelona.zendesk.com/hc/enus/articles/360000520808-Membership-Qualifications (accessed on 1 September 2018).

99. Scoot Networks. Personal Interview with the Vice President of European Market Development at Scoot Netwoks. 2018.

100. ACCIÓ L'empresa californiana de lloguer de vehicles elèctrics Scoot s'instal·la a Barcelona i crearà 60 llocs de treball aquest 2018. Available online: http://www.accio.gencat.cat/ca/accio/premsa-comunicacio/ cercador-premsa-actualitat/article/180604_Scoot (accessed on 1 September 2018).

101. Scoot Networks. Iberia SL Investment Project EIPP-20180527—Scoot: Multi-modal Shared Electric Vehicles. Available online: https:/ / ec.europa.eu/eipp/desktop/en/projects/project-9511.html (accessed on 6 September 2018). 
102. Scoot Networks. En tan solo tres semanas habéis contribuido a ahorrar 30,000 kg de Co2 en la ciudad de Barcelona. ¡Gracias a todos \#Scootlovers! Available on Twitter: pic.twitter.com/Thlw8E61DQ. @scoot_esp 2018 (accessed on 6 September 2018).

103. Ajuntament de Barcelona ¿Qué es Bicing y Bicing eléctrico? Bicing. Available online: https:/ /www.bicing. cat/es/informacion/que-es-bicing-y-bicing-electrico (accessed on 4 September 2018).

104. Donkey Republic. Bike Rental in Barcelona. Available online: https:/ /www.donkey.bike/cities/bike-rentalbarcelona / (accessed on 4 September 2018).

105. Donkey Republic. Donkey Republic Bike Owners. Available online: https:// owners.donkey.bike/ (accessed on 4 September 2018).

106. Scoot Networks About US-Barcelona. Available online: https://scoot.co/barcelona/about/ (accessed on 4 September 2018).

107. Scoot Networks. Somos Scoot y hemos aterrizado en Barcelona! Available online: https://scoot.co/stories / scootbcn/ (accessed on 4 September 2018).

108. Kerr, D. Scoot's Electric Motor Scooters Spread to Spain. Available online: https:/ /www.cnet.com/news / scoots-electric-motor-scooters-spread-to-barcelona-spain/ (accessed on 15 October 2018).

109. Scoot Networks. Scoot Launches in Barcelona with Faster Scooters and Electric Bikes. Available online: https:/ / www.prnewswire.com/news-releases/scoot-launches-in-barcelona-with-faster-scootersand-electric-bikes-300656152.html (accessed on 4 September 2018).

110. Adigital Adigital I Asociación Española de la Economía Digital. Available online: https://www.adigital.org/ (accessed on 4 September 2018).

111. Donkey Republic. Donkey Republic Introduction for Partners. 2015. Available online: https://www.donkey. bike/about/ (accessed on 5 September 2018).

112. Mellino, C. Finally ... Uber for Bicycles Is Here. Available online: https://www.ecowatch.com/finally-uberfor-bicycles-is-here-1882106198.html (accessed on 6 September 2018).

113. Shareable Interviewed: Michael Keating, founder and CEO of Scoot Networks. Available online: https: / / www.youtube.com/watch?v=fY7NIfzeBpU (accessed on 5 September 2018).

114. Scoot Networks. Scoot Networks on the App Store. Available online: https://itunes.apple.com/es/app/ scoot-networks /id1361793328?l=en\&mt=8 (accessed on 6 September 2018).

115. Beroud, B.; Anaya, E. Chapter 11-Private interventions in a public service: An analysis of public bicycle schemes. In Cycling and Sustainability; Transport and Sustainability; Parkin, J., Ed.; Emerald: Bingley, UK, 2012; pp. 269-301. ISBN 978-1-78052-298-2.

116. Donkey Republic. Welcome to the Donkey Republic. Available online: https://www.donkey.bike/about/ (accessed on 5 September 2018).

117. Benoit, S.; Baker, T.L.; Bolton, R.N.; Gruber, T.; Kandampully, J. A triadic framework for collaborative consumption (CC): Motives, activities and resources \& capabilities of actors. J. Bus. Res. 2017, 79, $219-227$.

118. Andreassen, T.W.; Lervik-Olsen, L.; Snyder, H.; Van Riel, A.C.; Sweeney, J.C.; Van Vaerenbergh, Y. Business model innovation and value-creation: The triadic way. J. Serv. Manag. 2018, 29, 883-906. [CrossRef]

119. Deutsche Welle Insolvent Bike-Sharer Obike Abandons Bicycles throughout Europe I DW I 11 July 2018. Available online: https:/ / p.dw.com/p/31HVU (accessed on 2 September 2018).

(C) 2019 by the authors. Licensee MDPI, Basel, Switzerland. This article is an open access article distributed under the terms and conditions of the Creative Commons Attribution (CC BY) license (http://creativecommons.org/licenses/by/4.0/). 